\title{
Anonymous, makeup artist
}

Anonymous has worked for more than fifteen years as a makeup artist on various film and television projects. In this conversation, she illuminates the invisible labor of makeup artists, including the intimacy they share with actors. The conversation also touches on the enduring value of organized labor despite the ongoing erosion of traditional protections and benefits.

Tell us a little about your job.

I have a lot of variety in my work. I do a small number of features, primarily lowbudget union shoots. I also work on episodic television and a lot of commercials. I book a lot of promos and up-fronts, which are my bread and butter. There's always a lot of demand for that work. And then I grab the occasional gig that comes my way: celebrity work or print work. Most makeup artists specialize. They work on features or episodic television. I am fortunate to have some variety, and I really enjoy that.

What accounts for the difference?

I do a lot of day playing, or day checking, which means I make myself available to work for a production that needs additional artists on a short-term basis. You fill in for a few days or, if you're available, a week or more. It allows you to jump from job to job. 
What's a typical working day like?

My day starts pretty early. In television, a standard call time is 5:30 a.m. In commercials or up-fronts, it starts a little later, around 6 or 7 a.m. I get up between 3 and 4 a.m. depending on my commute. We all have call times on the call sheet, which is when you're scheduled to be at the location. But my philosophy is that call time is work time. If my call time is 5:30 a.m., I am there with my gear unpacked and ready to go before 5:30 a.m. I don't want to be shoving a breakfast burrito in my mouth when talent shows up. So I always arrive about thirty minutes before my call time. I'm usually at work for anywhere between twelve and sixteen hours. A typical day is fourteen hours, but I've worked a twenty-two-hour shoot and any number in between.

What kinds of information do you get before the shoot?

It depends on the job. If it's a feature, you have preproduction time to break down the script before shooting begins. How long depends on the budget. I primarily work on lower-tier features with budgets from $\$ 5$ to $\$ 15$ million. There isn't always that much time or money, which means preproduction isn't going to be lengthy. I'll have a few weeks to look over the script, prep, and figure out supply costs. I do a lot of highbudget commercials. I typically have a week or so to prep those, though that doesn't mean I'm getting paid for that time. I'm reviewing storyboards and special requests to best assess what the project will require and make sure that my kit is stocked with the right materials. In general, we're expected to be ready to go with guns blazing.

\section{And you maintain your kit on your own dime?}

It depends on the show, but whatever kit fee you earn often doesn't cover what you're expected to provide. It's mostly a courtesy fee they provide us. In television, we'll sometimes receive a kit fee of $\$ 25$ per day. In commercials, it's roughly $\$ 50$ per day. You negotiate everything in the features world, so there isn't a consistent figure. When you're doing things like music videos or promos, it's at the discretion of the production coordinators.

\section{How did you become a makeup artist?}

It's different for everyone. I was trying to make the transition into production in the late 1990s, early 2000s. I worked full time as a national artist for a makeup line. It paid a modest salary with nice benefits. I would travel around the country promoting the line and training other artists. I worked out a schedule where I 
could travel Sunday through Thursday. This kept my weekends free for spec work, offering my services for free. It was common at the time for working directors who wanted to transition into another medium-say from commercials or music videos to television - to put together a modest budget for some work on the side to help them make the transition. I'm talking about budgets of around $\$ 40,000$ or less. I was working full time to pay my rent but jumping on every spec shoot I could find to build my professional network and get more credits under my belt.

I did that for a couple of years before I developed enough contacts to finally leave the cosmetics world. It was like jumping off a cliff. I was saying goodbye to a really successful career to become a full-time freelancer. I was saying goodbye to my salary and health benefits. I was starting over from scratch, often working for people who were younger than me. It was hard. But I was following my passion. I wanted to work in production. I was very fortunate that my husband was supportive. He said he didn't know how we were going to do this, but that we'd figure it out. Within six months, I was working regularly.

Now I get most of my work through personal recommendations. Those come from producers or coordinators or directors specifically asking for me. Sometimes a friend will be double-booked and they'll refer me. As you gain experience, you rely on those recommendations. People know you. People trust you. For example, I did three different shows this past year because I'd become closely acquainted with the department head and key makeup artist and they felt very comfortable having me as a third to cycle into their shows. On those shows, it wasn't a director or coordinator saying, "Oh, your department needs a third or fourth person. Let me go get them for you." It's the department head saying, "This is how I want my department to run and these are the people I want to be hiring this week."

\section{What's an aspect of your job that outsiders might find surprising?}

Makeup artists become so intimately acquainted with the cast. We form very tight family units with one another and with the actors we see for so long each day. We're seeing them at four or five in the morning, at their most vulnerable. Maybe they didn't have much sleep. Maybe they had a nasty breakup. Maybe they're puffy or hungover. We see them in ways that they don't normally let others see them. It's our job to finesse them to a place where they're calm and ready to work. So a big part of my job is getting them into the right state of mind. And that involves a tremendous amount of emotional labor. People can be nervous, uncomfortable, edgy, or antsy, but I almost always find a soft spot or avenue to conversation. I get in there and soothe them. We're not therapists, but it's our job to get them in the right mood. If they're not focused, calm, happy, or at least comfortable in their skins, they can't do anything for the director. It doesn't matter if it's a thirty-second commercial or a two-hour film. They're just not in the right headspace. It's my job to help get them 
there. I find it very natural and quite easy. One of my directors used to call me the talent whisperer because I could get even the angriest person ready to go to set.

How does it feel when you're not working?

Awful. It's the worst part of this job. There is no length of time that is good for me to be out of work. I get nervous after more than five days.

Why is it so awful?

There's nothing worse than having no control over your destiny week by week. You can only do so much to make it rain. You can call your peers and say, "I'd love to get some union hours. I'm looking for anything you can throw my way." You can call producers with whom you're friendly to remind them that you're ready to work. My friends who are salaried don't understand how I cope. No matter how miserable their jobs are, they say, "We don't know how you get through these times." I don't either! I lose my mind. It's terrifying. It's so disconcerting because there's no actionable thing you can do to change it. You're helpless. All you can do is remind people that you exist. You put yourself in the back of their head, and that's it. You're at the mercy of others. You're contingent labor.

I think it's even harder in the entertainment business. When you love what you do and you're in a creative industry and you're also a freelancer, if the phone doesn't ring, it feels very personal, whether it is or not. You start doubting your work and wonder whether you're ever going to get called again.

\section{Do you think this is typical?}

I don't know if anything is typical anymore. Some of the people who were my journeyman mentors, who taught and trained me in these classes when I entered the union, had worked in the studio system many years ago. There was a consistency in those days. You'd go in there and you'd be there twelve hours a day, five days a week. That was that. Whatever it called for. These days, nothing is typical.

\section{Would you have liked to work in the studio system of the old days?}

I think it would have been an extraordinary education. It would have been regular and consistent work. I also like that socialized work environment. But on the other hand, I like doing a lot of different things. I like bopping around because the working conditions have changed a lot. It can become a little tedious, and so many corners are cut these days. Once you're in a production for a month, you start seeing where all the little gaps and problems are and how they affect you. It becomes 
less fun and glossy. You get anxious to move on and do something new, to get a mental break from it.

\section{What kinds of cost cutting really get to you?}

The stuff that is penny wise and pound foolish. It's hard to pinpoint because examples sound so silly and mundane. It's not paying a couple hundred dollars for someone to have a partial prep day for an elaborate prosthetic, but then ordering $\$ 200$ of some bizarre vegan meal that the actor absolutely has to have on a given day. It's not putting in place things that will make production run smoothly, but instead indulging people with difficult temperaments who suddenly need this or that. Instead of doing what seems the most logical, we'll have elaborate discussions about where we borrow from Peter to pay Paul. A unit production manager or production coordinator will say to me, "I know your department needs it. I'll figure out a way to do it, but you have to give me time to rework this and figure out how to flip another line item." Why not just budget for the overage? I'll ask for boards, a breakdown, and a schedule, and I'll look at it and go, "You want us to get eight talent ready, plus twenty featured background actors? Listen, guys, we can be an hour late or you can spend $\$ 450$ for union scale and get me a swing assistant. And I think you'll be happy to extend that money. You can put them on an eight and skate. And at eight hours they'll skate off for $\$ 375$. How does that look to you?” It just doesn't make sense to me why simplicity is often greeted with resistance.

Is there generally less work today than there was five years ago?

Absolutely. So much work has left Southern California for other places. Louisiana. Georgia. Michigan. The Carolinas. There have been some efforts to slow the exodus, but even those efforts have been destructive. Unions have negotiated for what they now refer to as ultra-low-budget contracts, which are designed for ultralow-budget movies (and also new media productions) as a way to make them local union shoots despite their meager resources. This is important, because crew can stay here to work on a union shoot and earn the hours they need to remain active union members and most importantly keep their health insurance. But the pay is often pretty bad. You earn something not too far above minimum wage.

My understanding is that the negotiated rates were designed with the idea of stopping runaway production from leaving California. So they approve all of these super-low-budget union movies at rates that would never have existed even a couple years ago because of runaway production in order to slow runaway production. For these kinds of shoots, highly skilled craft workers are earning not too much more than fast food jobs just for the privilege of working near home.

In the union's mind, I guess, the alternative is not to work at all. So the agreement is taking an already difficult situation and making it worse. However, with 
the new tax credits going into effect this year, the hope is that more regularly salaried work will return home.

\section{Are you tempted to work outside Los Angeles?}

I prefer to make it work in Los Angeles. I have a friend, however, who has been living in Detroit for eight months with his wife. It's easy for them. They don't have children. They don't have pets. They just get up and go. But when you work out of state, you end up in this bubble. You eat, live, and breathe that project. If you're in Los Angeles, you're at least going back to your home after you're done for the day. There's more of a work-life balance. Well, there's at least some distinction between work and life!

I can't imagine being gone that long. Some people love it and thrive on it. I don't think it's for me, personally. But also on an emotional level, it's extremely sad to see so much business leave town. I don't want to be a part of the process that keeps pulling work away. This is what we do. This is where we do it. We are the entertainment capital of the world. Why work anywhere else?

Do you think your working conditions have changed? Given what you've said about runaway production, are there tensions or pressures that manifest on set because of the loss of work?

There are two different consequences that are somewhat related. First, the era of big personalities - what you might consider diva behavior-in hair, makeup, and costume seems to be over. At one time, certain artists could commandeer certain jobs at certain rates, no matter the budget. I think that era is gone. The industry doesn't allow for it anymore. There isn't that kind of elasticity of money anymore. The only time I see this happen is when there's a celebrity request that is hard and fast, and they will not use anyone else. We're worker bees now. There's no time or money for divas. Secondly, and in general, the department is being asked to do more and more with less and less, which in turn makes it feel somewhat less glamorous than it did not too long ago.

Some of what I'm about to say, of course, also has to do with industrial changes and financial pressures in the music business. For example, when I first came into this business there was a lot of cachet associated with working on music videos. When I started working, the big music videos were made with A-list talent. Makeup artists were going in and getting up to $\$ 4,000$ a day to work with the big-name artists. Now we're working for less. You're lucky if you get $\$ 300$ for doing a twelve- to fifteen-hour day. We have to tap into our kits a lot more. They don't reimburse us or offer kit fees. They might want some very elaborate hair and makeup that calls for a lot of things that normally would be budgeted but aren't now. And you have less and less time to get people ready. It's just a series of things that have made that work very 
unglamorous. It's gotten to the point where makeup artists avoid music videos. They'd rather collect unemployment than do a music video because they know the hours are long, productivity pressures are extremely tight, and it's just-not what it used to be.

Why did you want to join the union [Make-Up Artists and Hair Stylists Guild, IATSE, Local 706]?

When I first started out, I didn't know if I would ever be able to join the union. It seemed so distant and difficult because it is a rather closed club and many of the loopholes or back entrances to get in have quietly shut over the years. Local 706 seems harder than any other IA local to enter. It's also one of the most expensive.

I'm a bit of a socialist at heart. I thought the whole idea of the union is strength in numbers. You want to get as many union members as possible. Yet 706 keeps new people out as much as possible because they're trying to preserve the work for their core union members. It's a very weird double-edged sword that I haven't heard of with any other IA local. I believe in organized labor, and I want more union membership, not less.

\section{How do you become an active member of the union?}

The simplest answer is that you need to earn a certain number of hours and then pay your dues. Literally. It's thousands of dollars to join. And then quarterly dues are at least $\$ 250$. But there's a catch-22. To get in you have to work a lot of union hours, but you can't get union hours unless you're in the union. So it's extremely difficult.

There are basically three ways to get in the union. They sound very easy, but they're absolutely not. The most straightforward way to get into the union is to work thirty days on a nonunion film that flips partway through the production to become a union signatory. It's tough for makeup artists, though. When you have a small makeup department, there are two or three people. We can't flip a production because the producers will know it's us and can retaliate. But if you have a big group of ten to fifteen crew members, it's more difficult to pinpoint who initiated the flip-it's always good to have the grips and electricians on your side. They have a little bit more power because there's more of them to hide the whistleblower.

It's always a terrifying thing when a production flips. The union reps come and shut it down. Then the production is given two options. First, they can flip to union, which means you've got to go back and get more money. Sometimes it just can't happen, so the show dies. Everybody leaves and you have to start all over with a whole new crew. What traditionally happens is you don't try to flip a show until at least two thirds of it is in the can, so they don't want to replace you with scabs for continuity reasons. 
The second way is called the $60 / 60 / 60$. You have to have sixty production days in a year, three out of five years in a row. It doesn't sound like much, right? It breaks down to five or six days a month. The problem is that it has to be feature film or television and most of us don't work in that capacity alone. Our working days also come from press junkets, music videos, or on-air appearances, but you can't use them to qualify for 60/60/60. It's a very limited calculation. It's also a hassle to prove: you have to request a letter from every single payroll company and every single production company to document that you did the work. It's hard, and the documentation is time consuming.

The third way is to do ninety union commercial days in a year. That of course is a lot more days per month. I know a lot of people who initially came in on commercial contracts because back in the day, a nonunion artist could still work union commercials; it was kind of a back-door entrance. That loophole has since closed, but there was a time in which production would willingly approve nonunion artists for commercial jobs. It also helped if those artists had agency representation and the clients specifically asked for them. (There was also one soap opera that had a specialized contract that allowed nonunion members to work. But since it was also a back door, everyone wanted to get on that soap. Imagine a department head with a list of fifty eager artists all vying for the chance to sub in on that one show for eligible days!) The biggest challenge with this path is that your days don't roll over into the next calendar year. They expire. So it could take years and years to join if you fall short annually.

For me, after years of qualifying my hours I became a trainee, and finally a journeyman, in my union. That elevation involved years of work even after I joined the union. I had to continually document my days on various productions, and take months of weekend classes. I am now technically at the highest level that I can be in our union. It used to have a lot more meaning. These days producers don't care. They'll hire a trainee, but luckily as a journeyman, there is no project I'm barred from working on. For example, commercial artists cannot work on episodic television in our union. They have to elevate to a trainee position in order to do that. And some shows only want journeymen to work as department heads, although there are no longer any hard-and-fast rules about that. On a personal level, it feels great because I never thought a dozen years ago I'd ever get into the union the way I did. I never thought I'd be a trainee, and then when I was a trainee, I never thought I'd be a journeyman. I'm always shocked and pinch myself. I'm a journeyman! It's still remarkable. But it doesn't get you the same accolades that it would years ago.

\section{What do you need to do get your health benefits?}

My guild requires eight hundred hours annually. It keeps going up. But when you have the benefits, they're spectacular. You can have a family. You can have a partner 
or a spouse or children or other dependents all covered, virtually for free. It is remarkable. You get the same health insurance as Julia Roberts. But the problem is that you've got to earn those hours every year. And you start at zero each year. If you work more than eight hundred hours in a given year, you can bank up to four hundred hours for the following year. But any more than that, you just lose the hours.

I remember going to my first meetings where there were so many people who were jokingly called the "old timers." They had been in the union forever. They had gotten in fairly young and had been working for thirty to forty years. Many were now up in arms about changes to the health plan (the requirement was moving from six hundred to eight hundred hours). The contract stipulated more hours for less and less coverage. They were frantic and angry. But I was young, and it all looked so glossy to me. I felt I had made it. I was looking through the eyes of someone who was so delighted to be finally invited into the union after so many years of working. Now, looking back on those conversations, I understand why the process made the "old timers" so frustrated. It also hasn't stopped: our health care and pension qualifications and coverage have continued to erode, particularly in the last five to ten years.

You have a level of labor consciousness that seems rare among your generation. What do you think about your peers? When is the last time you saw more than twenty 706 members in the same room?

It's sad, because we have a couple thousand members and maybe thirty to sixty people attend a union meeting. It's sad because it reduces the opportunities to talk to one another within the union about our experiences on set. Unfortunately, the culture of our union has made it that way-no one talks.

I'm still learning from other great makeup artists who also are journeymen. I try to do it for other up-and-coming artists. It's so important to our craft and our collective future. It doesn't seem like there is enough dialogue. I think it's because runaway production makes things tight for everyone. Nobody wants to share information or resources. It also leads to fewer people coming to you for help or advice. In union meetings people aren't talking about it all that much. Everyone is very concerned about their livelihoods; everyone is concerned about whether they can stay here or if they have to move. So nobody wants to pass on and share information as much as they used to.

Do you think there's a mentality that, by keeping the membership limited, it protects members in some way?

Yes. I don't think it actually works, but I think that's what the union thinks. But if it works so well, why do we have these new union contracts that pay us next to nothing on certain projects? 
If you could wave your wand, what's the change you'd most like to see in the motion picture industry?

I would make sure union signatory companies never run anything nonunion. I've worked for a number of union signatory production companies that mostly specialize in commercials, promos, like cable TV and reality TV. But they run 50 percent of their jobs nonunion. They'll give the production a different name, even though it's the same address. Every time the union calls them, the union says, "You know you're in violation of your contract." But the producers somehow get away with it by simply changing the name of this one-off production entity. If they get a big enough budget, they do a union production. If they're desperate to get a client, they'll do it nonunion even though they use a union crew. It's very frustrating. And the union certainly tries to protect its members by calling them out. But there are dozens of jobs going on daily around the city and they can't hunt down every job, every day, to penalize the production. There isn't enough manpower for that. At a certain point, you wonder why the companies even signed the union contract. We lose our union rates and our hours every time we have to do a nonunion job with a union company. In fact, I probably lose 50 percent of my hours every year to signatory companies that violate their contracts.

\section{Do you think that's something that has increased?}

Absolutely. Because nobody wants to pay for anything anymore. When budgets are tighter, production companies find running the project nonunion helps keep everything on track. They can pay us a few hundred dollars less. They don't have meal penalties. They don't have health care costs.

I also would wave my wand to ensure that it's much more tenable for crew to join IATSE. We don't have enough collective bargaining power to improve conditions in Los Angeles.

It's taken me a second career and a lot of time to get to this point where I'm a journeyman and I can do the jobs that I enjoy doing, and I'm still trying to get to that next level, trying to secure work on higher-tiered contracts, trying to get bigger celebrities on my client list. I know it's a matter of time. It's perseverance. It's putting in all your effort and your hours. It's advocating for a strong union to better protect us, so that things like ultra-low-budget contracts wouldn't exist.

You do all that because there is no magic wand. 